\title{
Electro-Desalination of Sandstones With Cracks
}

\author{
Lisbeth M. Ottosen \\ Department of Civil Engineering, building 128, Technical University of Denmark, 2800 Lyngby, \\ Denmark, LO@byg.dtu.dk
}

\begin{abstract}
Historical stone monuments and buildings are lost due to salt induced decay. This paper deals with a method, electro-desalination (ED), in which an electric DC field is applied to the infected stones. The method utilizes that ions are transported (electromigrating) in the pore solution in the electric field. In the experimental work here, sandstone prisms were spiked with $\mathrm{NaCl}$ to high concentrations prior to ED. During the application of current, the Cl ions are electromigrating into a poultice at the anode, and Na ions into a poultice at the cathode. Damaged stones are often fragile and cracked, and the focus of this paper is to investigate experimentally if the salts are removed effectively from the stone parts next to a crack. In the lab experiments performed, a crack was cut half through the rectangular sandstone prisms perpendicular to the electric field. The results showed no delay on the ED process from the crack. All through the stone, very low concentrations of $\mathrm{Na}$ and $\mathrm{Cl}$ were reached. The concentration were even lower than the concentrations before the spiking. This finding of effective desalination around a crack is important, as it means that during ED, the poultice with electrodes can be placed around the cracked and fragile surfaces, and thus further damage from physical contact between poultice and fragile stone can be avoided.
\end{abstract}

Keywords: Salt Induced Decay, $\mathrm{NaCl}$, Sandstone, Electro-Desalination, Historical Buildings.

\section{Introduction}

Soluble salts cause damage to many historic stone buildings and monuments, and cultural heritage is lost. When water accesses the pore network of a stone, it may carry various salts in solution. Several mechanisms can subsequently cause crystal growth and crystallizationdissolution cycles, which can result in severe stone damage. The techniques to remove the damaging salts are few, and an overall effective method is lacking. The use of poultice materials to reduce the salt content of salt deteriorated objects is a long established technique in conservation (Sawdy-Heritage et al., 2008). However, due to the complex nature of salt problems within historic structures the result of such interventions can be variable and unpredictable. The amount and depth to which salts are mobilised, and where they are transported to, is dependent on the inter-relationship between the poultice and the substrate, the drying conditions and also the initial salt distribution (Sawdy-Heritage et al., 2008).

Another option is electro-desalination (ED), which is a method under development. ED is based on application of an electric DC potential gradient to the salt contaminated stone. The method utilizes that ions in the pore solution are transported by electromigration towards the electrode of opposite polarity when the electric field is applied. The electrodes are placed externally on the stone surface in electrode compartments with poultice, and the ions from the salts concentrate in the poultice during the treatment. When the poultices are removed after the $\mathrm{ED}$, the ions of the salts are removed with them.

Electrolysis of water occurs at both metallic electrodes: at the anode $\mathrm{H}_{2} \mathrm{O} \rightarrow 2 \mathrm{H}^{+}+1 / 2 \mathrm{O}_{2}(\mathrm{~g})$ 
$+2 \mathrm{e}^{-}$and at the cathode $2 \mathrm{H}_{2} \mathrm{O}+2 \mathrm{e}^{-} \rightarrow 2 \mathrm{OH}^{-}+\mathrm{H}_{2}(\mathrm{~g})$. As seen, $\mathrm{pH}$ decreases at the anode and increases at the cathode. It is necessary to neutralize the $\mathrm{pH}$ changes to prevent severe damage of the stone. The work by (Herinckx et al., 2011; Skibsted, 2013) underlined the importance of avoiding stone acidification, as in ED experiments without $\mathrm{pH}$ neutralization, the stones were severely damaged next to the anode. Use of a calcite rich clay poultice offers neutralization of the acidification from the anode (Rörig-Dalgaard, 2013). The calcite buffers the acid and the clay gives workability, so the poultice can have optimal contact to the stone surface during the treatment.

Previous research has shown that ED can be removed from high and damaging concentrations to very low concentrations in laboratory scale from different types of sandstones: Posta and Cotta sandstones (Ottosen and Christensen, 2012), Gotland Sandstone (Skibsted, 2013), Nexø sandstone (Pedersen et al., 2010), and granite (Feijoo et al., 2013). No limitation posed by the stone type has been reported. Also successful removal of different salts of chlorides (Ottosen and Christensen, 2012), nitrates (Skibsted et al., 2013) and sulphates (Ottosen, 2016) have been obtained.

An adyantage of ED over poultising is that whereas in poulticing the poultice needs to be covering the surface of the object, inclusive the most fragile parts, this is not necessary in ED. In ED, the poultice with electrodes can be placed around the fragile parts, and the electric field will distribute into the stone material. It has been shown experimentally that the salts can be removed from stone parts, which are not placed in the direct line between the electrodes, which means that e.g. carvings can be desalinated (Ottosen et ql., 2014; Feijoo et al., 2017; Ottosen.

2017).
Damaged stones are often cracked, and thus it is relevant to investigate if the salts are
removed efficiently around the cracks. The electric field can pass only through the moisture of
the pores and in case the crack is air-filled, it acts as an insulator, which the electric field ljnes
cannot pass. This work is an experimental investigation of the influence from a rnajor crack on
the ED process. Laboratory experiments are conducted with single sandstones, where a major

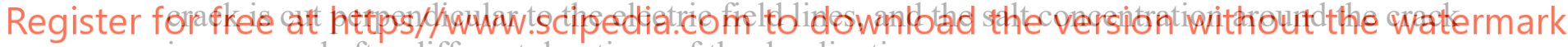
is measured after different durations of the desalination.

\section{Materials and Methods}

\subsection{Experimental Stones}

The experimental work was conducted with Gotland Sandstone. This type of stone was chosen, as it is relatively homogeneous and it is commonly used in Denmark. All sandstone pieces in this work were cut from the same block.

\subsection{Measuring Techniques}

For the measurement of $\mathrm{pH}$, conductivity and concentration of soluble $\mathrm{Cl}$ and $\mathrm{Na}$, the dried stone samples were grinded in a mechanical mortar. Following $10 \mathrm{~g}$ powder was suspended in $25 \mathrm{ml}$ distilled water and agitated for $24 \mathrm{~h}$. The samples settled for 10 min and $\mathrm{pH}$ was measured. The samples were filtered through $0.45 \mu \mathrm{m}$ filter. Na concentrations were measured by ICP-OES. Cl concentrations were measured by ion chromatography (IC, Dionex DX-120). The concentrations for each segment was measured as single determination. 
The open porosity and density of the Gotland Sandstone used in this work were determined (five replicates). Sanstone pieces of $170-190 \mathrm{~g}$ were dried $\left(105^{\circ} \mathrm{C}\right.$ for 24 hours), weighed $\left(\mathrm{m}_{\mathrm{dry}}\right)$, and placed in a desiccator under vacuum for approximately $3 \mathrm{~h}$. After $3 \mathrm{~h}$, distilled water at room temperature was led into the desiccator, so that the discs were completely submerged. Vacuum was maintained for $1 \mathrm{~h}$. Hereafter, air was let into the desiccator and the submerged discs were left at atmospheric pressure overnight. The water-saturated pieces were weighed in water $\left(\mathrm{m}_{\mathrm{sw}}\right)$ and in air after wiping excess water of the surface $\left(\mathrm{m}_{\mathrm{sa}}\right)$. The open porosity was calculated as $\left(\left(\left(\mathrm{m}_{\mathrm{sa}}-\mathrm{m}_{\mathrm{dry}}\right) /\left(\mathrm{m}_{\mathrm{sa}}-\mathrm{m}_{\mathrm{sw}}\right)\right) * 100 \%\right)$; and apparent density $\left(\left(\left(\mathrm{m}_{\mathrm{dry}}{ }^{*} \rho_{\mathrm{w}}\right) /\left(\mathrm{m}_{\mathrm{sa}}-\mathrm{m}_{\mathrm{sw}}\right)\right)\right.$, where $\rho_{\mathrm{w}}(970 \mathrm{~kg} / \mathrm{m} 3)$ is the density of water.

To have a uniform distribution of the salt prior to the experiments, the stone samples were contaminated with the salt in the lab: the stone prisms were dried at $105^{\circ} \mathrm{C}$ and vacuum saturated by $80 \mathrm{~g} / 1$ solution of $\mathrm{NaCl}$ in a desiccator prior to the ED experiments. The dry weight of the stone prisms before vacuum saturation $\left(\mathrm{m}_{\mathrm{d}}\right)$ and the stone weight after vacuum saturation $\left(\mathrm{m}_{0}\right)$ were measured and from these the initial water content was calculated as $\left.\left(m_{0}-m_{d}\right) / m_{d}\right) * 100 \%$.

\subsection{Electro-Desalination Experiments}

Four rectangular stone prisms were cut from the same stone block. The prisms were $13.5 \mathrm{~cm} \mathrm{x}$ $7.5 \mathrm{~cm} \times 5.5 \mathrm{~cm}$. A crack was cut half way through each prism in the middle, perpendicular to the longest side (and the electric field lines) (Figure 1). The width of the void was about $1 \mathrm{~mm}$.
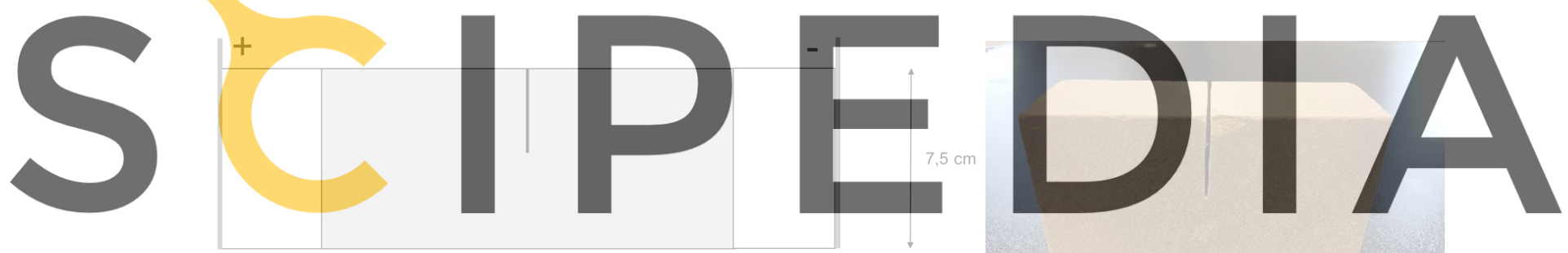

Register for free at https//wWwak.scipedia.com to download the version without the watermark

Figure 1. The setup for electro-desalination. The electrodes are placed in clay poultice on each end of the stone, and a crack is cut half into the stone perpendicular to the electric field.

Electrode compartments were placed at each end of the rectangular stone prism as illustrated in figure 1(a). For the electrode compartments a frame was folded in thin plastic to fit the surface of the stone at each side. The frames were filled with poultice; a mixture of kaolinite and $\mathrm{CaCO} 3$ [3] with an initial water content of 54\%. Inert platinum coated electrode meshes were placed at the end of each electrode compartment. The sandstone and electrode compartments were wrapped in plastic film to hinder evaporation. A reference stone (REF) was made with no applied current. The REF stone was wrapped in plastic film for 14 days. Three ED experiments were made differing only in duration: 2,4 and 5 weeks $\left(\mathrm{ED}_{2}, \mathrm{ED}_{4}\right.$ and $\left.\mathrm{ED}_{5}\right)$. A constant current of $10 \mathrm{~mA}$ was applied to the electrodes all through these experiments. Table 1 shows the dry weight $\left(\mathrm{m}_{\mathrm{d}}\right)$ of the different stone prisms, the water content after the vacuum saturation and the duration of the experiments in weeks. 
Table 1. REF and ED experiments. Dry weight of stone, initial water content after vacuum saturation and duration of experiment.

\begin{tabular}{lccc}
\hline & $\begin{array}{c}\text { Stone weight, } \mathrm{md} \\
(\mathrm{g})\end{array}$ & $\begin{array}{c}\text { Initial water } \\
\text { content }(\%)\end{array}$ & $\begin{array}{c}\text { Duration } \\
\text { (weeks) }\end{array}$ \\
\hline $\mathrm{REF}$ & 1072 & 10.2 & 2 (no current) \\
\hline $\mathrm{ED}_{2}$ & 1056 & 10.4 & 2 \\
\hline $\mathrm{ED}_{4}$ & 1084 & 10.5 & 4 \\
\hline $\mathrm{ED} 5$ & 1079 & 9.4 & 5 \\
\hline
\end{tabular}

After the REF and ED experiments, the stone prisms were segmented with hammer and chisel into 8 segments (Figure 2). The upper row of segments were named a-segments and the lower b-segments. All segments were weighed and dried $\left(24\right.$ hours at $\left.105^{\circ} \mathrm{C}\right)$, and the water content calculated. The dried segments were grinded in a mechanical mortar (FRITSCH pulverisette 9) for 10 seconds. Following, $10 \mathrm{~g}$ powder was suspended in $25 \mathrm{ml}$ distilled water and agitated for $24 \mathrm{~h}$. The samples settled for $10 \mathrm{~min}$ and $\mathrm{pH}$ was measured. The samples were filtered through $0.45 \mu \mathrm{m}$ filter. The $\mathrm{Cl}$ concentrations were analyzed by ion chromatography (IC, Dionex DX-120).
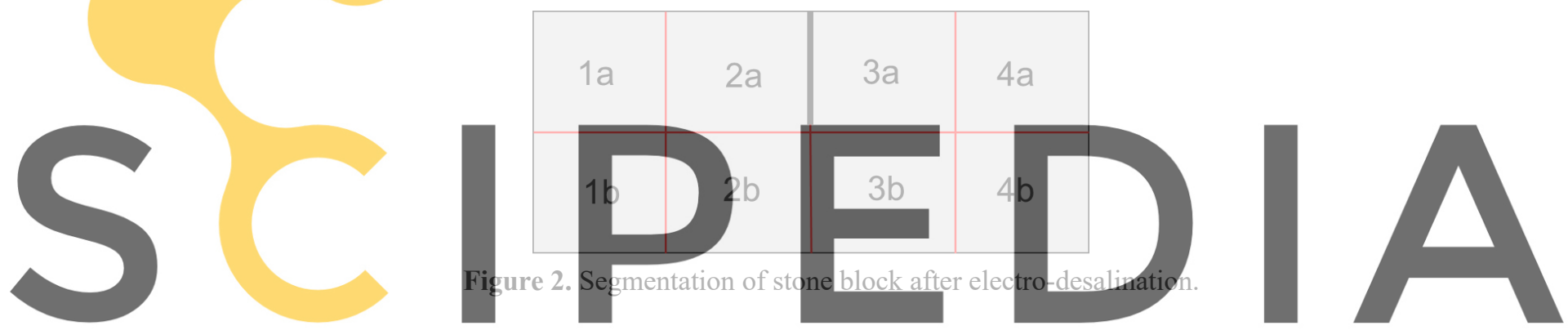

The poultices were changed every 7 th day. The poultices were weighed. The $\mathrm{Cl}$ and $\mathrm{Na}$

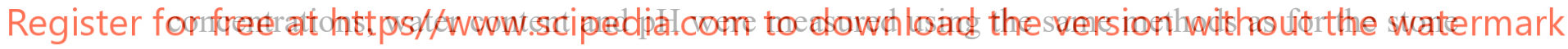
segments.

\section{Results and Discussion}

\subsection{Characteristics of the Sandstone}

The porosity of the Gotlandic sandstone used in the experimental work was $20.4 \% \pm 0.03 \%$, which is higher than previously reported (15\%) by (Nord and Tronner, 1995). The difference shows a natural variation in the porosity of Gotlandic sandstone. Nord and Tronner (1995) reported that the grey, calcitic Gotland sandstone is composed of about $60 \mathrm{wt} \%$ quartz grains, cemented together by $7-10 \mathrm{wt} \%$ calcite, and with lower amounts of clay minerals, micas, feldspar minerals, pyrite, and glanuconite.

The concentrations of $\mathrm{Cl}$ and $\mathrm{Na}$ before and after spiking with $\mathrm{NaCl}$ is shown in table 2 together with $\mathrm{pH}$ and conductivity. The salt concentration is similar to previous investigations with the same type of sandstone and concentration of $\mathrm{NaCl}$ in the spiking solution (Ottosen et al. 2014). 
Table 2. Concentrations of $\mathrm{Na}$ and $\mathrm{Cl}, \mathrm{pH}$ and conductivity of the stone before and after spiking with $\mathrm{NaCl}$.

\begin{tabular}{lcccc}
\hline & $\begin{array}{c}\mathrm{Na} \\
(\mathrm{mg} / \mathrm{kg})\end{array}$ & $\begin{array}{c}\mathrm{Cl} \\
(\mathrm{mg} / \mathrm{kg})\end{array}$ & $\begin{array}{c}\text { Conductivity } \\
(\mathrm{mS} / \mathrm{cm})\end{array}$ & $\mathrm{pH}$ \\
\hline Before spiking & $23.3 \pm 0.3$ & $21.4 \pm 4.2$ & $0.46 \pm 0.04$ & $8.6 \pm 0.04$ \\
\hline After spiking & $2520 \pm 230$ & $4200 \pm 130$ & $5.33 \pm 0.16$ & $9.1 \pm 0.1$ \\
\hline
\end{tabular}

\subsection{Electro-Desalination Results}

The concentrations of $\mathrm{Cl}$ and $\mathrm{Na}$ in the different segments after the REF and the three ED experiments are shown in figure 3. The decrease in concentrations is clear and the average concentrations were already about halved after two weeks.

(a)
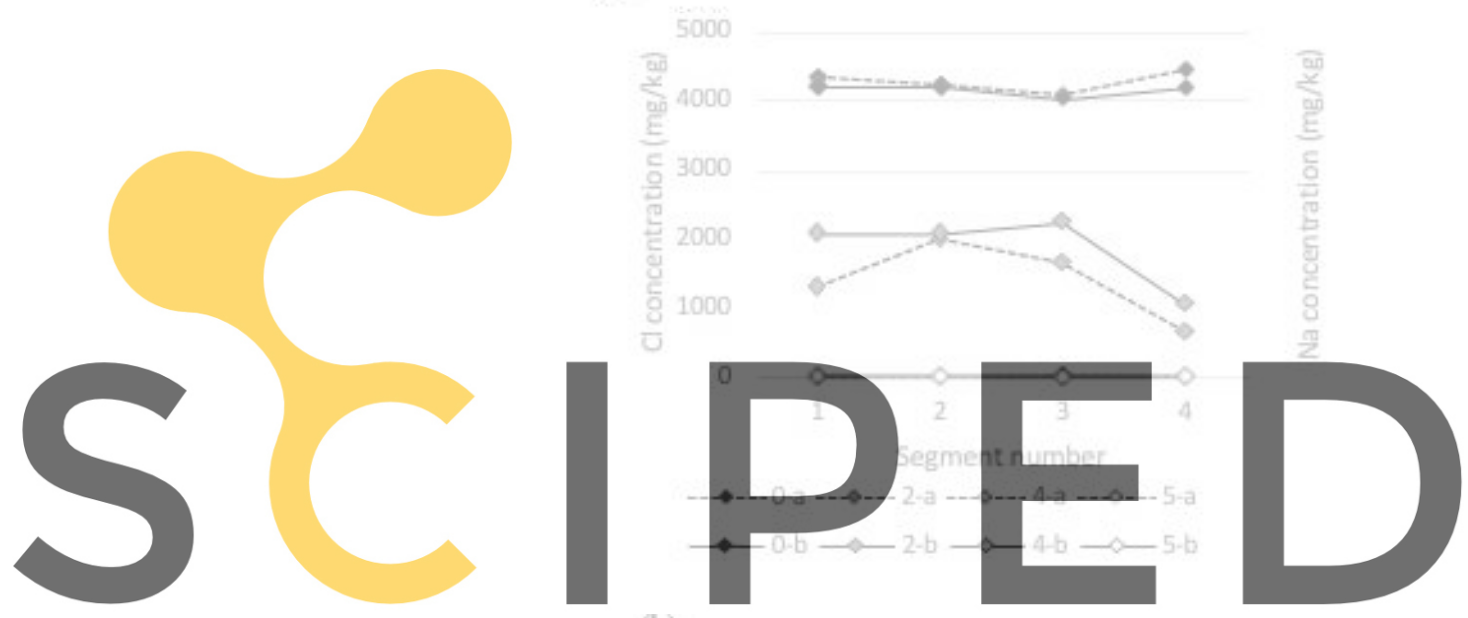

(b)
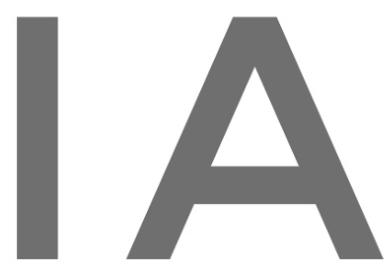

Register for free at https//www.scipedia.com to download the version without the watermark

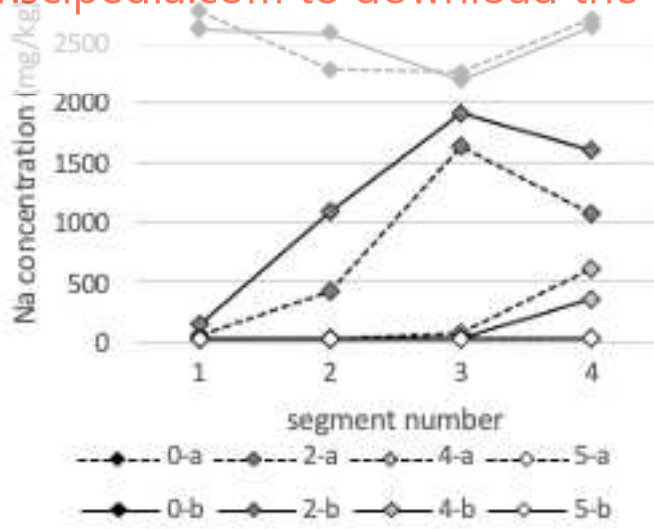

Figure 3. Concentration profiles of (a) $\mathrm{Cl}$ and (b) $\mathrm{Na}$ in the stone segments at the end of the experiments. The dotted lines are the profiles in the segment row with the crack (a-segments) and the full lines are the lower row of segments (b-segments). 
The final $\mathrm{Cl}$ concentration in all segments in $\mathrm{ED}_{4}$ was between 14 to $19 \mathrm{mg} \mathrm{Cl} / \mathrm{kg}$ (figure 3), which corresponds to a reduction of more than $99.5 \%$ in comparison to the $4200 \mathrm{mg} \mathrm{Cl} / \mathrm{kg}$, which was the initial concentration in the ED experiments (Table 2, concentration after spiking). The final $\mathrm{Cl}$ concentrations were even lower than the concentration in the stone before the spiking (21.4 $\mathrm{mg} \mathrm{Cl} / \mathrm{kg}$; table 2), and the $\mathrm{Cl}$ removal was successful all through the stone. Thus, the final $\mathrm{Cl}$ concentration in the segments next to the crack was not negatively influenced by the crack.

The Na removal was not finished in $\mathrm{ED}_{4}$ since the concentration was still 340 and $600 \mathrm{mg}$ $\mathrm{Na} / \mathrm{kg}$ in the segments closest to the cathode, $4 \mathrm{a}$ and $4 \mathrm{~b}$, respectively (figure 3 ). Thus, the removal of $\mathrm{Na}$ was slightly slower than the removal of $\mathrm{Cl}$. However, within one week longer treatment, the $\mathrm{Na}$ removal was successful, as in $\mathrm{ED}_{5}$ the concentrations in the segments were between 7 and $11 \mathrm{mg} \mathrm{Na} / \mathrm{kg}$, which was also less than before the spiking (2520 mg Na/kg).

The successful desalination was supported by the conductivity, which in the segments after $\mathrm{ED}_{5}$ was $0.096 \pm 0.007 \mathrm{mS} / \mathrm{cm}$ was also less than the $0.46 \pm 0.04 \mathrm{mS} / \mathrm{cm}$ prior to the spiking.

The $\mathrm{pH}$ in the segments after $\mathrm{ED}_{5}$ was between 9.7 and 10.3. Since the initial $\mathrm{pH}$ was 9.1 (table 2), the $\mathrm{pH}$ was increased all through the stone, and the acidic front was thus prevented in developing into the stone by the poultice.

In summary, $\mathrm{Na}$ and $\mathrm{Cl}$ were removed to very low concentrations in all stone segments during the ED treatment and after 5 weeks, the concentrations were lower than before the stones

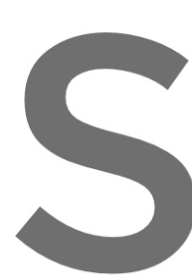
were spiked. Thus, thes

\section{Results from experin}

the poultice at the anoc

calculated from concen

In figure 4, the electrica

During the first approximately three weeks,

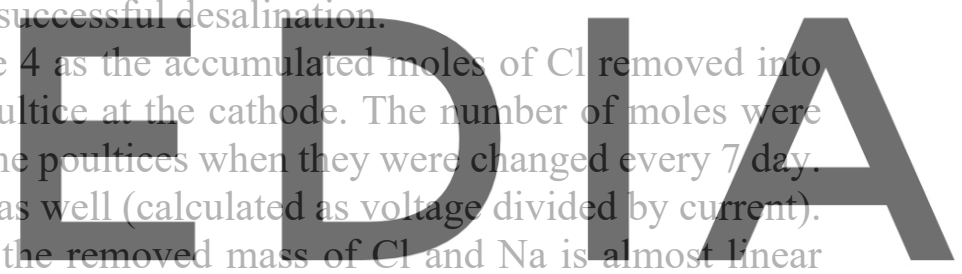

with the duration of the treatment, and in this period, the electrical resistivity is very low. After

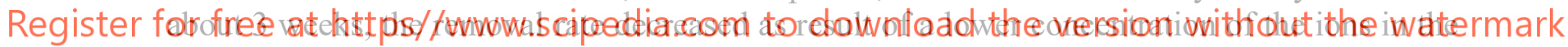
stone. After a little more than 3 weeks of treatment, it is also seen that the electrical resistivity increases dramatically corresponding to the low level of removal indicating lower salt content left in the stone. Thus, the time for the desalination to be finished is indicated by an increase in electrical conductivity. 

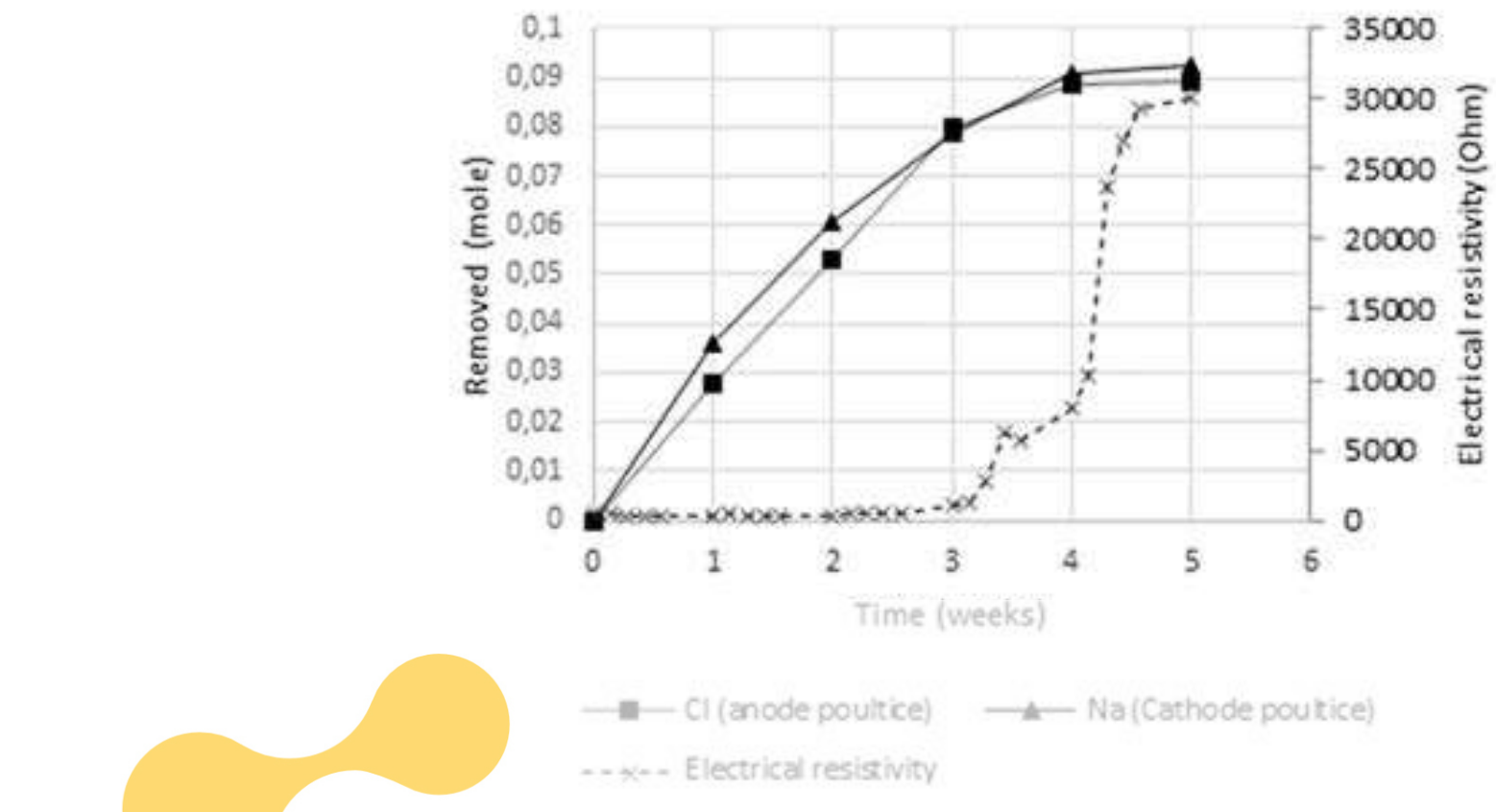

Figure 4. Number of moles $\mathrm{Cl}$ removed into in the anode poultice and $\mathrm{Na}$ into the cathode poultice over time in experiment EDs. The electrical resistivity over time in $\mathrm{ED}_{5}$ is shown as well.

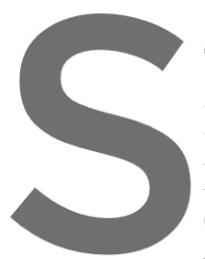

\section{Conclusions}

Electro-desalination

parts next to a crack.

$\mathrm{cm} \times 5.5 \mathrm{~cm})$ and electro
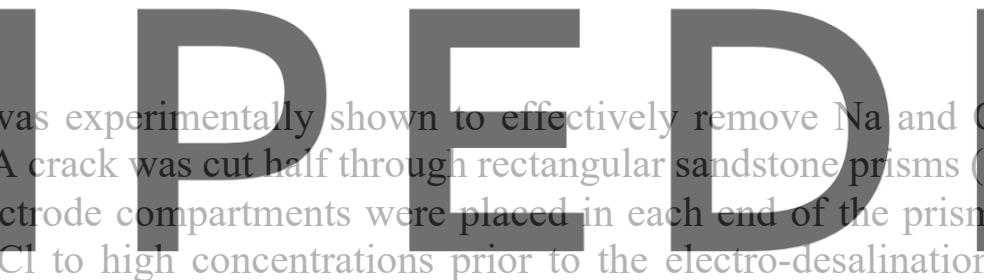

were spiked with $\mathrm{NaCt}$ to high concentrations prior to the electro-desalination, and after 5

weeks of treatment, the salts were removed again and even to concentrations lower than present

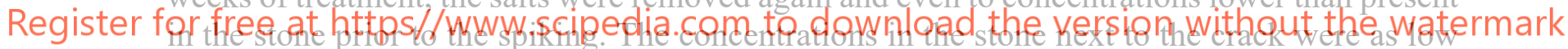

as in the other parts of the stone, and thus the interference of the crack on the overall desalination

is minor.

\section{ORCID}

Lisbeth M. Ottosen: https://orcid.org/0000-0001-7756-382X

\section{References}

Feijoo, J., Matycak, O., Ottosen, L.M., Rivas, T. and Nóvoa, X.R. (2017). Electrokinetic desalination of protruded areas of stone avoiding the direct contact with electrodes. Materials and Structures, 50(82), 15.

Feijoo, J., Nóvoa, X.R., Rivas, T., Mosquera, M.J., Taboada, J., Montojo, C. and Carrera, F. (2013). Granite desalination using electromigration. Influence of type of granite and saline contaminant. Journal of Cultural Heritage, 14, 365-376.

Herinckx, S., Vanhellemont, Y., Hendrickx, R., Roels, S. and De Clercq, H. (2011). Salt removal from stone building materials using an electric field. In: Proceedings from the international conference on salt weathering on building and stone sculptures, I. Iannou \& M. Theodoridou (eds.), Cyprus 19-22 October, 357-364.

Nord, A.G. and Tronner, K. (1995). Effect of acid rain on sandstone: The Royal Palace and the Riddarholm Church, Stockholm. Water Air and Soil Pollution, 85, 2719-2724.

Ottosen, L.M. (2016). Electro-desalination of sulfate contaminated carbonaceous sandstone - risk for salt induced decay during the process. In Science and Art: A Future for Stone: Proceedings of the 13th International Congress on the Deterioration and Conservation of Stone. Eds. John J. Hughes, Torsten Howind, 2, 897904. 
Ottosen, L.M. and Andersson, L.H. (2017). Electrode placement during electro-desalination of NaCl contaminated sandstone - simulating treatment of carved stones. SWBSS 2017, 4th International Conference on Salt Weathering of Buildings and Stone Sculptures. Potsdam, Germany, 20-22, 150-157.

Ottosen, L.M. and Christensen, I.V. (2012). Electrokinetic desalination of sandstones for NaCl removal - Test of different clay poultices at the electrodes. Electrochimica Acta. 86, 192- 202.

Ottosen, L.M., Skibsted, G. and Præstholm, T. (2014). Electrodesalination of sandstones with irregular shapes and uneven distribution of salts. Proceedings from SWBSS2014 3rd International Conference on Salt Weathering of Buildings and Stone Sculptures. Ed. H. De Clercq, 405-420.

Petersen, G., Ottosen, L.M. and Jensen, P.E. (2010). The possibility for using electrokinetics for desalination of sandstone with low porosity. Proceedings from 8 th fib International PhD Symposium in Civil Engineering. Kgs. Lyngby, Denmark, June 20-23, 455-460.

Rörig-Dalgaard, I. (2013). Development of a poultice for electrochemical desalination of porous building materials: desalination effect and $\mathrm{pH}$ changes. Materials and Structures, 46(6), 959-970.

Sawdy-Heritage, A. M., Heritage, A. and Pel, L. (2008). A review of salt transport in porous media : assessment methods and salt reduction treatments. In Salt weathering on buildings and stone sculptures (SWBSS), $22-$ 24, Copenhagen, Denmark.

Skibsted, G. (2013). Electrochemical desalination of limestone spiked with Na2SO4 - importance of buffering anode produced acid. Paper $\mathrm{E}$ in $\mathrm{PhD}$ thesis Matrix changes and side effects induced by electrokinetic treatment of porous and particulate materials, Technical University of Denmark.

Skibsted, G., Ottosen, L.M., Jensen, P.E. and Paz-Garcia, J.M. (2015). Electrochemical desalination of bricks Experimental and modeling. Electrochimica Acta, 181, 24-30.
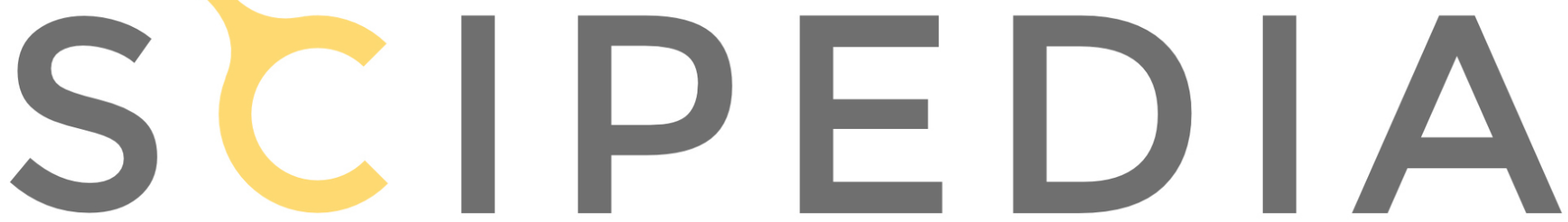

Register for free at https//www.scipedia.com to download the version without the watermark 